\title{
Rural-Urban Migration in China: Temporary Migrants in Search of Permanent Settlement
}

\author{
Beatriz Carrillo Garcia
}

\section{Institute for International Studies, University of Technology Sydney}

Since 1978, China's transitional economy has been characterized by its dynamism. Profound changes in its structure and the introduction of a market economy have intensified China's links to the outside world. The opening up of the economy and its strong regional ties with Asia Pacific have contributed to China's repositioning as one of the largest trading nations, and as a major player in the world economy. China is now the largest recipient of foreign investment, mainly as a result of increasing interest in its internal market and the availability of cheap labour. Economic reform has been a gradual process that has expanded from the East and South to the North and more recently to the Central and Western regions. Reactions to economic reform have varied from province to province, and economic development has been far from even. Regional variations make it difficult to come up with a generalized idea of the impact and meaning of economic reform.

Nevertheless, some common processes have been developing throughout the country. One of those has been the increasing internal movement of peoples. Massive population flows from rural to urban areas not only constitute 'the phenomenon of the century' (Zhang 1998) for China, they also constitute the largest flow of labour out of agriculture in world history (Taylor 2001, p. 5). These rural to urban migration flows have had consequences on almost every social, economic, and political issue in the People's Republic of China [PRC]. Migrants have been described both as agents of change at places of origin, and as essential contributors to economic growth in destination areas. ${ }^{1}$ Rural peasants - through migration - have become part of the globalization process and have also become the link through which rural and interior

\footnotetext{
${ }^{1}$ Roberts and Wei, for example, have shown how instrumental migrants have been in the economic growth of Shanghai. Tracing both official population growth and economic growth in this city since 1978, they found that registered population remained constant and then declined, while economic growth boomed. They state migrants provided the necessary labour to support this growth. Roberts, Kenneth D. \& Wei Jinsheng 1999, 'The Floating Population of Shanghai in the Mid-1990s', Asian and Pacific Migration Journal, vol. 8, no. 4, pp. 479-83.
} 
areas can be indirectly incorporated into that same process (Taylor 2001, pp. 5-11). In the case of China, regional economic integration has also been of great importance for economic growth and for the development of internal markets. The creation of an internal labour market is yet another result of this economic integration and the consequent division of labour.

Economic reform and international trade by themselves cannot explain the social dislocation created by the massive population movement experienced since the middle of the 1980s. Reform has also brought important policy changes in a wide range of sectors, of which relaxation on population mobility control is probably the most significant, with consequences not envisioned by the leadership of the Chinese Communist Party [CCP]. To understand the importance and magnitude of the growth in internal migration it is necessary to look back to the antecedents. The obvious characteristic of the current regime is the previous existence of a planned economy with particular socialist goals. The not so obvious include a restrictive population movement regime and a clear cut politico-administrative division between rural and urban populations. Before the 1980s - in line with socialist goals - the Communist regime had started an industrialization process in which urban areas were to be privileged and its proletarian class enhanced. The government then articulated a social security network that provided the urban population with free access to health care, education, grain and oil rations, as well as subsidized housing and lifetime employment. In the meantime, the rural population had been left to rely on its own resources through the commune for its daily necessities and received little economic help from the central government.

Since 1978 economic reform in the countryside and the introduction of rural markets gave households in those areas more freedom over the means of production and the allocation of labour. The incipient demand for labour in both rural enterprises and the service sector in the urban areas was responsible for attracting those who were surplus to agricultural production or who needed to diversify the household income. Despite the previous restrictions to entering the cities, the government started to lose its ability to control and restrict population movement. Nonetheless, the government could still make use of its household registration system (the hukou system) to keep those from 
the countryside separate and maintain its network of social benefits only for the official urban population.

The simple act of migration did not and still does not entitle a peasant to change their formal household registration, and only temporary residence permits and labour contracts are available for migrants. A change in registration status usually only occurs when a person is officially transferred; spontaneous migration has then no legal basis or support. As Solinger put it 'If the household registration changes, the person has migrated, if not, the person is floating' (1999, p. 15). The majority of migrants holds rural registration and is therefore not counted as part of the official population of cities, thus remaining part of the floating population. The latter category includes tourists, individuals attending meetings or doing business, as well as those who come to the city for medical treatment. However, migrant labour constitutes by far the biggest proportion of the floating population, frequently calculated as being as large as 100 million people.

The lack of an urban registration denies migrants the 'civic inclusion' that comes with the 'access to institutions that provide capacities and resources' (Solinger 1999, p. 4). Excluded from urban citizenship, migrants have developed their own resources to cope with the lack of public services. They have mainly relied on kinship and native place connections for mutual assistance and community formation at destination areas. Two of the most important outcomes of this congregation have been chain migration and the establishment of migrant enclaves. The more advanced of these entities have developed into self-sufficient communities separate from the state; offering cheap housing, job opportunities, schooling, and health care. Their activities fall outside any official jurisdiction, and are thus a possible source of social disunity. However, these complex communities are still a minority; most peasant migrants are not always able to organize such sophisticated organizations.

After a succinct description of the earlier internal migration regime prevalent in the PRC this paper will aim to chart and explain migrant flows into the cities, especially those of migrants with very little skills, few economic means or 'connections' (guanxi). Through the analysis of government institutions and policies it will explain the different consequences of the segmented incorporation of migrants into the cities. 
The analysis, although top-down, will include some of the migrants' responses to their exclusion in the cities. Conclusions point to the need to dismantle the hukou system and to expand welfare provision to incorporate all members of society.

\section{Internal Migration Before 1978}

China's past is full of examples of large-scale population flows, but these came to an end in 1954 shortly after the foundation of the PRC. It was only after 1978, and then again on a larger scale after 1984 - as a result of important policy changes on population mobility - that population movement became a significant issue again. This change is highlighted by the earlier background of a restrictive migration regime in place during the Mao era, which left no room for spontaneous migration. These antecedents are crucial to understanding both the problems and challenges that a process of such magnitude presents not only for the government but for society in general. The core of that problematic is to be found in the social dichotomy that has prevailed between rural and urban residents, which creates economic, political, and status differentiation.

The aftermath of the Chinese Civil War saw important internal population movement. Most of the people on the move were those being relocated to their home villages, or those entering the cities in search for employment; cities became magnets for rural peasants who looked forward to becoming recipients of state benefits. However, the government soon became aware of the increasing number of peasants entering the urban areas and the problems this posed for the construction of socialism, especially in terms of employment provision (Cheng and Selden 1994, p. 650). By 1954 government officials were already criticizing the 'blind flow' of people into the cities, ${ }^{2}$ and soon thereafter restrictions on mobility became a reality for most part of the following three decades.

One of the major tools used by the government to check population movement was the household registration or hukou system. Chan and Zhang have described it as 'one

\footnotetext{
${ }^{2}$ That same year the new Constitution established in its Article 90 that both freedom of residence and freedom to change residence were to be guaranteed. This freedom of movement and of residence was never again mentioned in official documents after 1955. Cheng, Tiejun \& Selden, Mark 1994, 'The Origins and Social Consequences of China’s Hukou System’, The China Quarterly, no. 139, p. 646.
} 
of the major tools of social control used by the state,' and as 'part of a larger economic and political system set up to serve multiple state interests' (1999, p. 819). The hukou system divided population into four categories, which in turn separated Chinese society into two major groups. The first two categories refer to a person's place of registration or hukou suozaidi (rural or urban), and the other two deal with a person's type of registration or hukou leibie (agricultural or non-agricultural) (Chan and Zhang 1999, pp. 821-22; Wu 1994, pp. 674-75). This registration system drew a clear distinction between the agricultural labour force and that of the cities, creating spatial hierarchies between city and countryside (Cheng and Selden 1994, p. 644). Each household was supposed to have a registration book though, in reality, registration was tied to the workplace (Lei Guang 2001, p. 482).

The hukou system by itself was not able to successfully control population movement. Government control over other economic and social activities helped maintain hukou differentiation and kept migration at low levels (Chan and Zhang 1999; Cheng and Selden 1999; Lei Guang 2001; Roberts \& Wei 1999; Solinger 1999; Davin 1999). The state monopoly over job and housing allocation, grain rationing, and a strict enforcement of the hukou system in urban areas - aided by the surveillance of local residence committees (Davin 1999, p. 7) - hindered peasants from moving into the cities.

Recruitment policies where dictated by the central government, which restricted urban enterprises' employment of peasant workers. Although it is also true that government did allow for temporary urban labour contracts from the rural areas - as was notably the case during the Great Leap Forward - as soon as their contracts ended peasants had to return to their place of origin. Moreover, after the disaster of the Great Leap Forward labour migration was halted and net urban migration rates greatly decreased. Rural to urban migration was also discouraged through the rationing and distribution of grain and other products of first necessity, like cooking oil, fuel and cloth (Davin 1999, p. 7). Without grain ration coupons and without an official contract from a state enterprise it was close to impossible for peasants to stay in the cities for long periods. By securely closing the cities from rural in-migrants the government was able to guarantee a series of social privileges - free access to health care services, education, grain rations, subsidized housing and lifetime employment - to city dwellers. 
Meanwhile, the rural population was left to depend on the communes for subsistence and received no further economic help from the central government. Commune resources were mostly pooled from local rural households, who ultimately financed most local social and welfare services (Ibid., p. 66).

\section{Economic Reform and the Consequences for Population Mobility}

The pre-reform migration regime was successful in establishing an artificial division in China's population, which was believed to be the foundation of socialist economic goals and social order. Reform, introduced at the end of 1978, gradually changed the economic structure of the PRC, and in turn brought about dramatic social changes. Increased population mobility has been one of the processes unchained by reform with far greater social consequences than originally envisaged. With time, it has come to be perceived by central and local authorities as the biggest threat to social unity and stability.

The introduction of local markets - first in the rural areas, later on throughout the whole country - the official adoption of a market oriented economy in 1992 and the opening up of the economy to foreign trade and investment were responsible for an increasing labour demand that lay the foundations for an incipient labour market. Eastern coastal provinces became large magnets for rural labour, a process triggered by the boom of town and village enterprises [TVEs] and by the economic dynamism that resulted from the reception by these provinces of large shares of domestic and foreign investment (Davin 1999, p. 57). Responding to those demands and looking for better economic opportunities tens of millions of peasants have migrated to the eastern coastal cities and other interior urban areas in search of work.

Mobility was first enhanced by the newly implemented household responsibility system [HRS], which in 1982 dismantled the communes and gave rural households individual contracts to farm agricultural land (Lei Guang 2001, pp. 483-84). A more efficient and productive use of resources - including labour - allowed for greater agricultural output and income, as markets for rural products thrived. The household became the main unit of production, at the same time that it acquired greater freedom of labour allocation as well as in migration decisions (Keely 2000, p. 51). Both 
household size and structure (the household development cycle) ${ }^{3}$ as well as land cultivation needs became important determinants of household surplus labour (Mallee 2000, pp. 42-6).

In order to diversify the household income, surplus labour began to engage in offfarm work. However, the pull factor created by enterprise labour demand lead many peasant workers to leave the countryside even when they were not surplus to agricultural production (Croll \& Huang 1997, p. 139). In line with government policy to keep peasants in the rural areas, those peasants were channeled to the newly established town and village enterprises [TVEs], which by 1996 already employed 30 per cent of the rural workforce (Davin 1999, p. 41). TVEs, however, were not able to absorb surplus labour for very long. Job creation in rural enterprises started to decline from the late 1980s, with a strong downturn between 1989 and 1990, when 14.5 million employees were fired from rural enterprises (Zhang 1998). Meanwhile, the big metropolitan areas started to attract an increasing number of migrants (Zhao Yaohui 2000, p. 22), thanks to relaxations on employment through non-state channels that allowed foreign and private sectors to become important employers.

The HRS and the development of rural markets have at the same time helped break the state monopoly over grain rationing. Higher productivity levels in rural areas allowed farmers to comply with state grain quotas, while retaining considerable surpluses that can be sold at higher market prices. The availability of grain in the market made it possible for migrants to buy grain at urban destinations without the need for ration coupons. Moreover, mobility has further been ensured by a set of policies diminishing central state control over provincial and lower administrative units, which can now establish their own economic priorities. The new provincial and local economic strategies - especially in middle and larger urban areas - include bringing in cheap labour to work in construction, manufacturing and other service sectors. On the other side of the spectrum, decentralization policies in the rural areas have encouraged local governments to actively promote and facilitate out-migration in

\footnotetext{
${ }^{3}$ Number of household working members, their age, marital status, education, etc. Mallee, Hein 2000, 'Agricultural Labor and Rural Population Mobility: Some Observations' in West, Loraine A. \& Yaohui Zhao (eds.), Rural Labor Flows in China, Institute of East Asian Studies, University of California, Berkeley, p. 45.
} 
order to increase village living standards through migrant's remittances. Increasing proportions of rural households and village income are indeed being derived from both migration and other non-agricultural activities.

\section{Urbanization and the Management of Migration}

Urbanization through migration has been described by development theorists as one of the major consequences of industrialization. That has been China's case since economic reform began. However, China's industrialization did not begin in 1978, but had been launched with the First Five Year Economic Plan in the 1950s. As already described, throughout the Mao era authorities were urged to check urban growth, and mechanisms were employed to keep the rural population away from the cities and urbanization rates low. The main reason for this policy was the heavy economic burden of supporting the urban population, which needed to be provided with a wide range of benefits plus a social security system. Between 1950 and 1977 urban population grew at 2.7 percent per annum (Wu 1994, p. 691); increasing from a share of 12.46 per cent of total population in 1952 to a 17.34 per cent share in 1977, even when the total population had increased by more than 400 million (Figure 1). These figures show both the low rates of urbanization and policy efficiency on internal migration control. Despite low urban growth, Chinese cities suffered from poor and insufficient infrastructure development, and together with demographic explosion put severe pressure on an already crammed living environment.

Figure 1: China's urban population growth

\begin{tabular}{|l|l|l|l|}
\hline Year & $\begin{array}{l}\text { Total } \\
\text { Population }\end{array}$ & $\begin{array}{l}\text { Urban } \\
\text { Population }\end{array}$ & $\begin{array}{l}\text { Proportion } \\
\text { \% }\end{array}$ \\
\hline 1952 & $574,820,000$ & $71,630,000$ & 12.46 \\
\hline 1977 & $924,200,000$ & $160,300,000$ & 17.34 \\
\hline 1990 & $1,143,330,000$ & $301,910,000$ & 26.41 \\
\hline 1999 & $1,259,090,000$ & $388,920,000$ & 30.89 \\
\hline
\end{tabular}

Source: China Statistical Yearbook, 1999.

Given the low standard of living in the places that migrants came from, large numbers of migrants responding to rural economic incentives were only to be expected. Income differentials as well as labour demand in industry and the service sector soon attracted 
the rural population, even when moving into urban areas did not necessarily mean gaining the same benefits as the local population. The gradual breakdown of the state monopoly over the different means of population mobility control was accompanied by a gradual modification of the hukou system. The reform of this registration system has been an on going process that is supposed to lead to the abolition of the system in the near future. The State Development Planning Commission announced in 2001 its aim to abolish the hukou system in the following 5 years (China Reforms Residence Registration System), however, registration still continues to play an important role in the reconfiguration of Chinese society. This, as will be explained later, has had important implications for the type and permanence of migrants; the relationship between urban dwellers and rural migrants in the cities; migrant settlement and adaptation in urban areas; and for the relationship between migrants and their place of origin.

The reasons behind the prevalence of the hukou system are rooted in the rural-urban dichotomy and the 'urban benefits network' created in the 1950s. Even when the government lost its power to restrict entrance into the cities, the registration system still allows local governments to deny migrants access to essential public services and goods. The system has also allowed the government to retain a certain degree of control over permanent settlement in urban areas, although its role has been one of a more regulatory character. Migration scholars have stressed the importance of government intervention in shaping recent migration processes, while describing government actions as an attempt 'to ensure that the state retains a critical role in reconstituting the rural-urban divide in China' (Lei Guang 2001, p. 483). The new settings - which include the introduction of a market economy - allow migrants into the cities but institutionalize their discrimination and commodification. The rush for economic gain seems to have permeated through government institutions, with bureaucrats benefiting from the cheap labour provided by peasant migrants, but also wining important cash incomes through fees imposed on outsiders or even through the commodification of local registration (Solinger 1999; Chan \& Zhang 1999).

How did rural-urban migration start? Besides officially sanctioned migration of sent down youths - who were allowed to return to the cities and recover their urban registration - a more subtle and less state organized movement of people started to 
take place in the 1980s. Even though all outsiders staying in urban areas for more than three days had to get approval from different agencies at both place of origin and at their destination, until 1984 there was no regulatory framework that dealt with migrants who intended to stay for longer periods in the cities. That year, for the first time, the government officially sanctioned migration into smaller urban areas, providing migrants brought or acquired their own grain at a non-subsidized price, and that they relinquished their agricultural land in their home village. The new policy allowed many de facto migrants to legalize their situation and that of their families, but still left them out of the urban social security network. The promotion of migration into small towns was part of an attempt to develop rural industries, to keep peasants in the countryside 'litu bu lixiang' (leave the soil but not the countryside), and to reduce the movement of people into the larger urban areas (Davin 1999, p. 41).

That same year, the central government introduced a temporary resident permit for all urban centers. Rural migrants older than sixteen had to obtain migration approval at place of origin and register with the public security bureau at destination, in order to apply for a temporary residence permit that had to be periodically renewed (Woon 1999, p. 478). The introduction of this temporary permit triggered the establishment of a locally based migrant registration system, where each city implements its own set of temporary permits, classifying migrants depending on their duration of stay, as well as their education and income levels or their contributions to the local economy. In time the new classification created a stratification of migrants, with educated and wealthier migrants able to gain easier access to a local hukou. The new regime of temporary permits varies greatly with the size of the city. Again, small urban areas offer greater facilities for migrants who want to acquire local registration.

The promotion of smaller urban areas was later on backed by a redefinition of urban categories and boundaries. At the same, a new urban categorization that allowed for towns to have lower proportions of non-agricultural population, resulted in the establishment of 3,430 new towns in 1984 (and increasing the total number of towns to 6,211); but reduced the proportion of non-agricultural population of those towns from 72 per cent to 39 per cent of total urban population (Wu 1994, p. 681). This trend resulted from the influx of rural migrants who acquired a temporary residence permit in those towns, but who maintained their rural registration. Even though this 
new redefinition has mainly affected smaller urban areas, some larger cities have also seen their population enlarged with the inclusion of suburban rural areas into their jurisdiction.

The locally based system of temporary residence permits and the commodification of urban registration led the central government in 1992 to approve a locally valid urban registration, referred to as the 'blue-stamp' card. This registration system was approved by the Central government on the principle of 'local need, local benefit, local responsibility, local validity’ (Chan \& Zhang 1999, p. 838). Eligibility for a blue stamp card in the big cities like Shanghai, Beijing and Shenzhen requires extremely high educational levels and skills, as well as high income levels; while the smaller urban centers demand little or no skills and charge much lower fees to migrants (Woon 1999, p. 499). The blue stamp card, however, is not synonymous with a permanent local hukou, and even when holders of this kind of permit can have access to many of the public services denied to temporary workers, they enjoy limited rights and obligations compared to those of the official urban population. In general migrants with a blue stamp card are considered 'preparatory' residents, who will soon acquire permanent status (Chan \& Zhang 1999, p. 839).

The various temporary migration regimes have also followed government policy promoting urbanization in smaller towns, while implementing a strict filter on migrants entering the larger metropolises. The new regime shows increasing practices of residence permit commodification, and a clear cut delineation of who is to be fully incorporated and who is not. These practices leave poorer peasant migrants who do not have the required skills with little possibility of changing their hukou status. Furthermore, they relegate them to temporary settlers who can make no claims on any of the public services of the cities or even lobby for the betterment of their situation, keeping them peripheral to urban life and development.

\section{Temporary Migration, Translocality, and the Creation of Distinct Labour}

\section{Markets}

Temporary and circular migration have dominated internal population flows in China since the late 1970s. One of the reasons for this trend has been the relationship of migration to agricultural cultivation cycles. Many of the peasants engaged in off-farm 
work and those who have migrated as a result of the introduction of the HRS are not surplus to production all year round. Therefore, if their labour is indispensable for agricultural production, seasonal mobility becomes their only option (Mallee 2000, p. 42). It has also been common for young married man in the countryside to migrate and leave their spouses in charge of farming, coming back when cultivation cycles require their labour contribution.

In many rural areas, however, returns from agriculture have severely decreased, while investment costs for improving the quality of the land are increasingly on the rise (Croll \& Huang 1997, p. 137). Farming has ceased to be a priority for many rural households, who nevertheless have to hold on to their land (the right to use the land) in order to be able to comply with prevalent state grain quotas, and because the land represents the only asset they can call upon when employment in rural or urban enterprises is slack. This practice has been described as the major obstacle to the consolidation of farmland and the modernization of agriculture, as well as being blamed for the deterioration of land resources (Woon 1999, p. 499). Deteriorating conditions in the countryside have sometimes led migrants to bring the whole family to the urban areas, where migration represents more of a survival than an income diversification strategy.

Up until the 1990s most of the rural labour movement happening in China had been to nearby destinations (Roberts \& Wei 1999, p. 478). Peasant workers generally choose off-farm work in local enterprises over migration, and it has been observed that rural areas with more opportunities for local non-agricultural employment usually have fewer migrants (Croll \& Huang 1997, p. 134). Nevertheless, more recent research has shown migrants are increasingly traveling longer distances to find work (Rozelle et al. 1999; Liang 2002). Migration decisions, however, imply making considerations beyond the purely economic; traveling longer distances and the prospect of having an unstable condition in the city can have high psychological costs for rural migrants (Zhao 1999, p. 778-79). Strong links with the place of origin and with agriculture are in great part the consequence of that semi-settled condition of peasant migrants in the cities. 
Migrants' temporality in the cities has a close relationship with the legal restrictions on permanent settlement, and is also closely linked with the need to secure the flow of remittances to the countryside (Schmitter 2000, p. 84). This situation reinforces the ties between migrants and their place of origin, turning migration into a translocal phenomenon 'whereby migrants operate in social fields that transgress geographic, political, and cultural borders,' and where home and host society act as a single arena of social action (Brettel 2000, p. 104). The translocal arena represents more secure ground for migrants, because most of their social links - and sometimes even their economic connections - remain those with their fellow villagers, even though they are interacting in two or more geographical locations.

In line with structural models of incorporation, where host society institutions interact with the specific characteristics of the newcomers (Alba \& Nee 1997), the hukou system has only allowed for a segmented integration of peasants into urban life. The migrant labour market has remained a secondary labour market 'of unskilled jobs, poor wages, and insecure employment' (Schmitter 2000, p. 81), showing no signs of integration with the local urban labour market (West 2000, p. 9). Those migrants who secured employment in a State Owned Enterprise [SOE] have faired better than those working in the collective or the private sector. Jobs at SOEs gave greater stability than those in the other economic sectors, and in some cases provide basic services of housing and health care (Roberts \& Wei 1999, p. 503). Until the mid 1990s, SOEs and collectives were still the major employers in China, but their share of urban recruitment is expected to decline as these enterprises experience restructuring or bankruptcy processes. Many of those enterprises are laying off their permanent workers and hiring temporary migrants, precisely because they offer cheaper labour and the company is not obliged to give them any benefits. Nowadays, even the state owned sector does not represent a securer employer, since temporary workers can always be easily laid off (Davin 1999, p. 99).

Since 1995 some of the larger cities like Shanghai, Shenzhen, and Beijing have restricted migrants' access into different job categories, limited their participation in some sectors, or completely banned them from others (Lei Guang 20001, p. 492). One newspaper article in Beijing, for example, announced that from 2002 migrant labour excluding nannies - could only account for 20 per cent of total labour employed in the 
service sector of the city (Beijing Qingnianbao Oct. 29, 2001). Moreover, some employers have even established specific requirements aimed at discarding the rural applicants. One employer insisted applicants should be of at least a minimum specified height. The purpose of this requirement was to get rid of the short people, who tended to be from the countryside and would therefore not be suitable for the job (Davin 1999, p. 104).

These regulations show the increasing obstacles imposed both by urban authorities and by employers to exclude poorer and less educated migrants from entering the primary labour market, reducing their chances for upward mobility. Other artificial barriers include high housing costs and regulations making it harder for migrants to rent housing in the cities, pushing them to suburban areas where the lack of social services and police protection is pervasive (Zhao 1999, p. 778). In the larger cities rural migrants are increasingly being pushed into the periphery both in geographical and economic terms; assimilation with the larger urban society has been possible in very few cases. Smaller urban centers have shown a higher degree of marketization of housing and basic food items, making it easier for migrants to access cheaper housing and food stuffs (Woon 1999, p. 498), a situation that could enhance closer interaction between migrants and locals. This hypothesis needs to be further tested; so far the few studies documenting the situation of rural migrant workers in small urban areas and villages have had mixed results. In her field research in a small town in the Western Delta of the Pearl River in Guandong Province, Woon (1999) found that migrants are 'well integrated into the community.' 'They socialize with and receive help from local people and cadres' (p. 492). Migrants in this area of the province have helped fill the labour gap created by big numbers of locals migrating to the United States. In another study by Yang Yao in four villages located in the east coast, Yang describes the persistent exclusion of migrants from the local community (2001, p. 9).

Despite the rhetoric of more openness, extensive hukou reform has been a reality only in the smaller and medium urban centers, which are less attractive for migrants or which are not able to provide enough good job opportunities for the rural labour surplus. Even when those urban areas can offer migrants an equal residence status to that of the rest of their official population, it is mostly the case that public services and urban benefits are severely limited or lacking in these cities. Urbanization through 
amalgamation of rural population - the result of a government strategy to increase urban population without incurring the costs of expanding public services and social security systems - could well be a solution for overcrowded metropolises, but is doomed to fail if conditions in the small and medium urban centers are not improved.

\section{Networks, Chain Migration, and Migrant Enclaves}

Nowadays, migrant presence in urban areas is highly visible. In 1990 the 'floating population' in the eight largest cities of China already accounted for between 11.1 to 27.5 percent of the total de facto urban population (Ma \& Xiang 1998, p. 546). In 1990 temporary migrants accounted for 37.8 percent of the population of Hangzhou and 12.4 percent of the population of Tianjin, while by 1994 those migrants made up a quarter of the population of Beijing (Davin 1999, p. 107). Migrants are everywhere doing all kinds of jobs mostly in the service and informal sectors. They are mainly engaged in the 3-D jobs - difficult, dirty, and dangerous (Ma \& Xiang 1998, p. 547) jobs that the urban population does not want because they are too hard or demeaning. 'In cities like Beijing, where local people are reluctant to do such work, migrants predominate to such an extent that there are complaints when enterprises close at Chinese New Year in order to allow their workers to return home for the holiday.' (Ibid., p. 102).

Some migrants have been in the cities for long periods, others - from nearby rural areas - stay in the cities for shorter periods, returning on a more regular basis. There are those who come to the cities to sell their vegetables, fruits, rice or chickens. Others collect cans, bottles, or carton and get together at informal sites to sell their merchandise. Migrant women form a large part of the waitresses in restaurants and hotels, and are also commonly seen doing menial work in shops and other public places. In busy intersections one can come across migrants with small carts selling food or doing all kinds of repairs. Train stations are another place where migrants usually gather, waiting for possible employment or waiting for a train to go back home.

Regardless of whether or not they have secured a job before coming to the city, migrants' situation in the cities is not an easy one. Their condition is similar to that of a non-citizen in a foreign country; they are not considered full members of the host 
society, and their presence is regarded as temporary. Residence permits have to be renewed every year for a fee, and it is also common for migrants to be charged with other fees throughout the year. Although the Ministry of Labour has recommended certificates should not cost migrants more than 10 yuan, one finding showed that in 1996 migrants were spending around 223 yuan each year to pay for certificates and an employment card (Zhao Yaohui 2000, p. 24). Many migrants who want to avoid the fees do not register with the local public security bureau, making their situation even more vulnerable.

There has been a closer watch on temporary migrants and an overemphasis on clamping down on crime believed to be committed mostly by migrants, especially by those without legal documents (Zhao Shukai 2000, pp. 101-4). Those without a proper registration certificate become easy target for the police, who can extract money from them or who could until last year 'deport' them back to their home village. A State Council decision late in 2003 banned the custody and repatriation system used to detain migrant workers, after a college graduate and migrant worker from Hubei province was beaten to death by the police in a Guangzhou detention centre (Tong Yi 2003). Clashes, however, have taken place not only with the police but also with local residents, who - as in many other societies - are not happy about the increasing presence of migrants.

Because of the vulnerability of their situation, migration has to be a well prepared and planned event. Networks - ties of kinship or friendship - have been the key to facilitating migration, and securing work and accommodation at the place of destination. Rural institutional barriers - like the household responsibility system and transportation have not represented big obstacles for migration (Rozelle et al., p. 369). The fact that migrants are increasingly traveling longer distances in search for work confirms this. Social networks and chain migration have played an exceptional role promoting internal population movements. Not only do they reduce the costs and risks of migration, but they provide help with settlement and adaptation. Such an important role for chain migration in China is considered to be related to 'the poor institutional structure available to migrants at urban areas' (Rozelle et al., p. 390). Chain migration has then become a cumulative process where 'each act of migration itself creates the social structure needed to sustain it' (Brettel 2000, p. 107). 
Migrants bring their relatives and friends to the cities, find them a job at their workplace or else employ them or establish joint small businesses with them. Accommodation varies according to the type of activity they perform. Construction workers are commonly housed next to their worksite, with accommodation varying depending on the size of the project. Some employers provide workers with austere dormitories; in other cases workers have to build shacks or find tents to live in. Migrant sales people use their stalls as living quarters, while many waitresses have to sleep in the restaurants where they work. There are accounts of waitresses working for up to sixteen hours and spending the night sleeping on a chair (Solinger 1999). Maids and nannies live with their employers. The rest of the migrants live in hotels, hostels or rentals, while others camp out. Finding a place to live is not an easy task. Cheap housing is commonly not available in the city, pushing migrants to the suburban areas where they rent rooms from local households. About 40 per cent of migrants live in the homes of residents (Solinger 1995, p. 133) either staying with friends and relatives, or renting a room from the locals.

The problem of unsatisfactory housing is an important one. None of the different types of accommodation mentioned seems to be reliable or suitable for permanent settlement. Not only that, their location at the periphery means they seldom interact with urbanites and assimilation is almost non-existent (Zhao 1999, p. 767). 'Instead, they formed a patchwork of people in "parallel communities," plus some stragglers, all of them eking out existences for the most part outside the state' (Solinger 1999, p. 242). In both the labour force and society migrants are a clearly distinct and separate group in the urban environment. They have reshaped the physical and social landscape of Chinese cities, but that has still not won them a better position inside those cities.

Community formation has been one of migrants' responses to improve their living environment. Migrant enclaves not only offer cheaper housing, but can sometimes have well organized - though simple - education and health care premises. Some migrant communities have been able to create successful enclave economies that provide a good alternative to the secondary labour market to which migrants are relegated (Schmitter 2000, p. 81); but also offering opportunities for capital 
accumulation that can be invested in education or other means of upward mobility (Solinger 1995, p. 117). 'A relatively complex division of labor within their trade also works to enhance the potential for the provision of community welfare' (Solinger 1999, p. 251), representing safer ground for migrants who decide to bring their spouse and children to the cities. Even though family migration accounts for a very small percentage of total migrants (3.6 per cent) (Zhao Yaohui 2000, p. 26), the Ministry of Education estimated that in 1996 there were between 2 and 3 million children with migrant parents in urban areas in 1996 (Davin 1999, p. 106). Migrant enclave formation has taken place over the last ten to fifteen years, and is the result of chain migration; reflecting not only an increase of migrants and their families in the host cities, but proving that more migrants are setting roots there.

Migrant enclaves have been structured around their ties with the place of origin; the sense of belonging that 'plays a powerful role in shaping migrant behavior at both ends of the migration spectrum' (Ma \& Xiang 1998, p. 557). These enclaves have become so important for some villages that they have established offices to protect the interests of their laoxiang (native-place fellows) at destination areas (Ibid., p. 561). Enclaves have been set up in suburban areas, which have been partially urbanized by migrants and their economic activities (Davin 1999, p. 108). The most important and better studied migrant communities are those established in Beijing; 'Zhejiang Village' being the largest one, followed by 'Xinjiang Village', and by other less cohesive and geographically differentiated communities like 'Henan Village' and 'Anhui Village’ (Ma \& Xiang 1998, p. 567-69). There are also other accounts of community and shantytown formation in Guangzhou, Shenzhen, and in Shanghai’s Pudong District (Solinger 1999, p. 250).

Migrant enclaves act as self-contained communities of people from the same province, county or village, who engage in a specific economic activity. Zhejiang Village has specialized in garment production; Xinjiang Village is the place for halal restaurants; Henan villagers are engaged in collecting garbage and waste materials; while Anhui Village has been an important vegetable market (Ma \& Xiang, p. 566). Not all enclaves offer the same security or show the same degree of organization and community solidarity. Zhejiang Village has been the most successful case, becoming a 'comparatively stable community,' where 'increasingly winning toleration from the 
state arises from its extraordinary economic success' (Davin 1999, p. 111). Many of the residents in this village are successful entrepreneurs who have the economic means but do not have the urban hukou.

Because they are regarded as informal settlements the government provides no services to these communities. In the case of Zhejiang Village, the community has been able to organize its own schools, clinics and hospitals, restaurants, child-care centers, hairdressers, repair shops, and markets, as well as make-shift toilets and longdistance phone lines (Solinger 1999, p. 254). This complex system allows its residents to have access to services that they would otherwise not be able to obtain from the government because of their lack of urban registration. The quality of the services is not comparable to that of state-provided ones, but they are better than having no services at all.

Recently, periodic police sweepings have threatened the stability of these enclaves. After it was announced that Beijing had finally been selected to hold the 2008 Olympic games, authorities have launched several initiatives to clean and beautify the city. Migrant enclaves have been specifically targeted by the new policy. Not only are stalls and small enterprises being torn down, migrant schools have also been threatened with closure. ${ }^{4}$ Most migrant families cannot afford to enroll their children in local public schools, since they would have to pay the higher tuition fees that apply to those who do not hold an urban hukou. They also fear their children will be looked down upon by local children. The services provided by their community are therefore indispensable in the daily lives and economic activities of migrants. Parents can drop their children at the child-care centers or at the local schools and be relieved that they can offer their children at least a basic education, while they are working for the improvement of their condition. Zhejiang village, however, remains an exceptional case; most migrants usually do not count with such sophisticated community organizations and have to cope with the lack of free health care and education services, and their exclusion from the social security system with few alternatives.

\footnotetext{
${ }^{4}$ Eckholm, Erick 2001, 'District in Beijing to Shut Schools for Migrants' New York Times 31, Oct. An earlier campaign carried out by the central and Beijing government in November-December 1995, left most migrant housing compounds demolished. Li Zhang 2001, 'Migration and privatization of space and power in late socialist China’, American Ethnologist, vol. 28, no. 1, pp. 192-194.
} 


\section{Challenging Institutions: Urban Citizenship and the Need for Migrant Inclusion}

With the implementation of economic reform and the introduction of a market economy, government institutions and its social system have been challenged and transformed. The regime has been able to reinvent itself and retain an important role reshaping economic, political, and social institutions, though with different degrees of agreement and discontent. Reform has certainly benefited the majority of the population, but as transition advances ruralites are being left behind. It has become evident that some regions, especially large urban areas, have particularly benefited from economic reform. Not only have income disparities between rural and urban areas been significantly enlarged since the mid 1980s, the income gap between the rich eastern coastal areas and inland regions has also widened. Per capita GDP in the poorest province, Guizhou, is now only 8 per cent of per capita GDP in the wealthiest, Shanghai (Wang \& Hu 1999, p. 200).

Internal migration in China has been both a response to those income disparities and to increased mobility and individual freedom. Embedded in the dichotomy between urban and rural populations, internal migration has challenged the earlier social order by bringing that duality to the cities. The consequences of rural to urban population movements have been manifold, but it has become evident that the situation of migrants in the cities demands further transformation and even dislocation of the old institutions governing people's lives. At the core of the problem are those institutions that confer and deny rights and privileges to different members of society.

Even though the government can no longer restrict the entrance of peasants into the cities, through the hukou system it is still able to establish who can and who cannot be a legitimate urban citizen. Those with a rural registration - without the necessary skills, economic means or connections - are being increasingly discriminated against and segregated from the rest of the urban population. They are being treated as noncitizens and denied of the rights bestowed on the urban population, just by the fact of their registration status. Denying urban citizenship to those members of society, as Marshall has stated, has important consequences for social inequality and cohesion (cited in Schmitter 2000, p. 85), creating increasing class differentiation in a society that once praised itself on its equality. This and other social problems - like unemployment and the surge of urban poverty - have moved social issues to the fore 
on the PRC's domestic agenda. Social stability has indeed been a top government priority, and is considered to be a prerequisite of a smooth economic transition and of the continuation of the political supremacy of the CCP.

Reform of the hukou system has been high on the central government agenda since the 1980s, although it was only until 1993 that the government considered abolishing the system altogether. Relaxation of population mobility control, together with the decentralization of decision making, allowed local governments to regulate migrant labour more closely, in accordance with their economic priorities. Urban registration became a new commodity and authorities were quick to benefit from it. A wide range of temporary residence permits allowed for migrants' stratification according to their skills, income levels, and duration at destination. Only a small minority with the human capital, economic means, plus the necessary connections (guanxi) was to be able to gain (or buy) legal permanent urban registration. The system has been relaxed to allow further urbanization in the small and medium urban areas, but it is still restrictive in the larger cities.

The problem with the reform of the hukou system rests in its implications for the provision of urban benefits and the expansion of the social security system. Since reform started those same urban benefits have been dwindling, and the state is no longer 'holding itself responsible for allocating public goods even to its native urban dwellers' (Solinger 1999, p. 287). Employment, health care, and education are being offered in the non-state sector, while securities are soon to be opened to foreign investors (China further opens insurance market, China Daily). Many urban workers are no longer part of the benefits package channeled through State Owned Enterprises, while private and collective enterprises are rarely filling the gap on welfare provision. Nevertheless, important reforms in health care and retirement pensions have been proposed or are already being implemented with the aim of including all urban workers (New Socialized Medicare to Benefit more people, Xinhuanet). The education system has also been reformed and upgraded, and there has been a slow deregulation of housing prices. The problem with these reforms is that they fail to include temporary migrant workers or the rural areas, further widening the disparities between the urban and the rural while keeping rural migrant workers as second-class citizens. 
Recently, Beijing announced a new medical insurance scheme that will incorporate all self-employed and freelancers (Healthy Reform Covers All, Xinhuanet). The announcement, however, clearly stated the new provision will only apply to 'all selfemployed individuals registered in an urban household in the capital', leaving no room for the inclusion of temporary workers and migrant entrepreneurs. Most migrants have to bear all medical costs themselves, and when seriously ill may opt to return to their villages rather than pay the prohibitive medical fees of urban hospitals and clinics. This is part of a prevailing practice where 'administrative management agencies plan their work and projects only in accord with the size of the registered permanent population within their respective jurisdiction' (Wu Ruijun cited in Solinger 1999, p. 16); without consideration of the hundreds of thousands of migrants who represent an important proportion of the population of most large cities in China.

As with healthcare provision, peasant transients have to deal with the lack of other basic services that are considered fundamental for the integration of newcomers, and which are rights established by law for all citizen of the PRC. Compulsory education for all children between seven and twelve years old is stipulated in China's Law on Compulsory Education (Solinger 1999, p. 266), although in very few cases have urban authorities been willing to grant that right to migrant children. Migrant parents who can not afford to educate their children in the city, either leave them behind in the countryside or else bring them to the cities as apprentices, receiving no formal education (Solinger 1995, p. 119). Some citizenship scholars have regarded the right and duty to receive education as 'the most universally approximated implementation of national citizenship’ (Solinger 1999, p. 266). Moreover, education has generally been recognized as an important mechanism for upward mobility. Improving skills and literacy levels can thus offer opportunities for better jobs.

However, not only have migrant workers been channeled into a secondary labour market, but also the jobs available to them usually demand few skills and rarely provide training. The recently promulgated Labour Law (1994) stipulating workers’ equal right to employment and choice of occupation has not stopped urban governments from securing specify jobs only for official residents (Zhang 1998). Conditions vary with place and industry, but the general situation does not look very 
promising. As enterprises become more dependant on migrant labour, employers might be pushed to offer better deals for their workers. One research report indicated that enterprises with higher proportions of migrant workers 'are more willing to take measures to retain migrant employees by providing housing, transferring household registration, and arranging education for migrant's children' (Tan \& Ma cited in Zhao Yaohui 2000, p. 12). This, however, is not a general trend. Migrant workers are increasingly being hired precisely because there is no obligation to provide them with any benefit or service. Because of the poor skills development among migrant labour some experts worry China's large labour population will lack skills and know how necessary for economic development and international competition (Zhang 1998).

For the migrants this situation means much more than just losing international competitiveness. They complain about pervasive discrimination and the lack of guarantee of their rights (Solinger 1999, p. 247), a situation that makes their future in the cities highly unstable and unpredictable. The inhospitability of the urban environment has led migrants to rely more and more on their connections with those of their native place, friends, or relatives. They have come to realize that the government has little intention of incorporating those that - in their opinion - can contribute very little to the urban environment. 'These people, though nationals, were barred by the hukou prohibition from acquiring city citizenship and so were denied any means of pressing their needs legally on urban and higher-level governments' (Solinger 1999, p. 252). Up until now migrants’ organizations have been very loose and temporary, although there have been a considerable number of illegal strikes and demonstrations staged by migrant workers. Close watch by local police makes organization a risky endeavor. However, even government advisors recognize that 'once they get organizations with an educated leadership and a political program, the floating rural population could be molded into a political force, a mobile, armed, and formidable antisocial coalition’ (Lei Guang 2001, p. 491).

The formation of migrant communities and enclaves that aims to develop self-reliant groups separate from the state is a direct response to that segregation. These enclaves might be able to promote the economic mobility of their members, but they can also deter their incorporation into the larger social spectrum (Brettel 2000, p. 112). Furthermore, as has already been stated, enclaves can develop direct antagonism 
towards local government and societies, thus becoming a possible threat for social unity. Even though the possibility of migrants' organizations becoming a political opponent of the Communist Party is still far from a reality, there is a real possibility of social unrest if migrant's issues and problems are not given prompt responses and solutions. The recent accession of the PRC to the World Trade Organization [WTO] might further increase the pressure to abolish the hukou system altogether (Chi Fulin 2001, pp. 10-12), though that would only be part of the solution to migrant exclusion.

Including migrants into the official population of the cities will allow local authorities to better control migrant groups, while allowing closer contacts between the two. Only by giving migrants a fairer treatment can authorities build a relationship of mutual trust, one that can allow for mutual cooperation to stop illegal commercial activities and crime. The costs of incorporating those migrants do not have to be absorbed solely by the state; local governments can 'withdraw from some activities in the provision of insurance and basic social services in order to leave more space for private for-profit and non-profit engagement' (Jutting 1999, p. 3). A recent report on the reform of China's social security system emphasizes this idea of expanding social security provision through a socialized system where enterprises from all economic sectors are included (Song 2001, pp. 5-10). Dismantling the hukou system has therefore become a crucial requirement for reverting the rural-urban divide and for the incorporation of millions of peasant migrants, who have for almost two decades been a central element of urban development. 


\section{Reference List}

'China Further Opens Insurance market', China Daily [Online] (Nov. 23, 2001)

Available: www.chinadaily.com.cn

'China Reforms Residence Registration System', China Radio International [Online] Available: http://web12.cri.com.cn/english/2001/Oct/34288.htm [Accessed 1 Nov., 2001]

'Healthy Reform Covers All', Xinhuanet [Online] (Nov. 22, 2001) Available: http://news.xinhuanet.com/english.htm

'New Socialized Medicare System to Benefit More People', Xinhuanet [Online] (Nov. 22, 2001) Available: http://news.xinhuanet.com/english.htm

Alba, Richard \& Nee, Victor 1997, 'Rethinking Assimilation Theory for a New Era of Immigration', International Migration Review, vol. 31, no. 4, pp. 826-74.

Brettel, Caroline B. 2000 'Theorizing Migration in Anthropology. The Social Construction of Networks, Identities, Communities, and Globalspaces' in Brettel, Caroline B. \& Hollifield, James F. (eds.), Migration Theory, Routledge, pp. 97-135.

Chan, Kam Wing \& Li Zhang 1999, 'The Hukou System and Rural-Urban Migration in China: Processes and Changes', The China Quarterly, no. 160, pp. 818-55.

Cheng, Tiejun \& Selden, Mark 1994, 'The Origins and Social Consequences of China’s Hukou System’, The China Quarterly, no.139, pp. 644-68.

Chi Fulin 2001, 'WTO Accession Will Accelerate Reforms in China. An Action Plan to Address the Most Pressing Issues', World Bank Transition Newsletter, vol. 12, no. 3, pp. 10-12. [Online] Available: http://www.worldbank.org/transitionnewsletter/Archives/2001.htm

China Statistical Yearbook, 1999.

Croll, Elisabeth J. \& Huang Ping 1997, 'Migration For and Against Agriculture in Eight Chinese Villages', The China Quarterly, no. 149, pp. 128-46.

Davin, Delia 1999, Internal Migration in Contemporary China, MacMillan Press.

Eckholm, Erick 2001, 'District in Beijing to Shut Schools for Migrants', New York Times, Oct. 31.

Jutting, Johannes 1999, 'Strengthening Social Security Systems in Rural Areas of Developing Countries' ZEF Discussion Papers on Development Policy, Center for Development Research. [Online] Available: http://www.zef.de

Keely, Charles B. 2000, 'Demography and International Migration' in Brettel, Caroline B. \& Hollifield, James F. (eds.), Migration Theory, Routledge, pp. 4360.

Lei Guang 2001, 'Reconstituting the Rural-Urban Divide: peasant migration and the rise of 'orderly migration' in contemporary China', Journal of Contemporary China, vol. 10, no. 28, pp. 471-93.

Ma, Laurence J. C. \& Biao Xiang 1998, 'Native Place, Migration and the Emergence of Peasant Enclaves in Beijing', The China Quarterly, no. 155, pp. 547-81.

Mallee, Hein 2000, 'Agricultural Labor and Rural Population Mobility: Some Observations' in Loraine A. West and Yaohui Zhao (eds.), Rural Labor Flows in China, Institute of East Asian Studies, University of California, Berkeley, pp. 34-66.

Mallee, Hein 1998, 'Definitions and Methodology in Chinese Migration Studies' in Bakken, Borge (ed.), Migration in China, Nordic Institute of Asian Studies, pp. 107-44.

Murphy, Rachel 2002, How Migrant Labor is Changing Rural China, Cambridge University Press. 
Roberts, Kenneth D. \& Wei Jinsheng 1999, 'The Floating Population of Shanghai in the Mid-1990’s', Asian and Pacific Migration Journal, vol. 8, no. 4, pp. 473510.

Rozelle, Scott et al. 1999, 'Leaving China's Farms. Survey Results of New Paths and Remaining Hurdles to Rural Migration’, The China Quarterly, no. 158, pp. 36793.

Schmitter Heisler, Barbara 2000, 'The Sociology of Immigration. From Assimilation to Segmented Integration, from the American Experience to the Global Arena' in Brettel, Caroline B. \& Hollifield, James F. (eds.), Migration Theory, Routledge, pp. 77-96.

Solinger, Dorothy J. 1999, Contesting Citizenship in Urban China. Peasant Migrants, the State, and the Logic of the Market, University of California Press.

Solinger, Dorothy J. 1995, 'The floating population in the cities: chances for assimilation?', in Davis, Deborah S. et al. (eds.), Urban Spaces in Contemporary China, Cambridge University Press, pp. 113-39.

Song Xiaowu (ed.) 2001, Report on the Reform and Development of China's Social Security System, Renmin University Publishing House.

Taylor, J. Edward 2001, 'Microeconomics of Globalization: Evidence from Mexico, China, El Salvador, and the Galapagos Islands' Report to the Latin America and Caribbean Regional Office of The World Bank.

Tong Yi 2003, 'Kidnapping by Police: Custody and Repatriation', China Rights Forum, No. 2.

Wang Shaoguang \& Hu Angang 1999, The Political Economy of Uneven Development: The Case of China, M E Sharpe, Armonk, New York.

West, Loraine A. 2000, 'Introduction' in West, Loraine A. \& Yaohui Zhao (eds.), Rural Labor Flows in China, Institute of East Asian Studies, University of California, Berkeley, pp. 1-14.

Woon, Yuen-Fong 1999, 'Labor Migration in the 1990’s. Homeward Orientation of Migrants in the Pearl River Delta Region and Its Implications for Interior China', Modern China, vol. 25, no. 4, pp. 475-512.

Wu, Harry Xiaoying 1994, 'Rural to Urban Migration in the People's Republic of China', The China Quarterly, no.139, pp. 669-98.

Yang Yao 2001, 'Social Exclusion and Economic Discrimination: The Status of Migrants in China’s Coastal Rural Areas', China Center for Economic Research, Working Paper No. E2001005 (April 19).

Zhang, Li 2001, 'Migration and privatization of space and power in late socialist China', American Ethnologist, vol. 28, no. 1, pp. 179-205.

Zhang, Xianchu 1998, 'Some Legal and Social Issues Concerning the Rural Labour Migration in China' Unpublished paper.

Zhao Shukai (translated by Andrew Kipnis) 2000, 'Criminality And The Policing Of Migrant Workers’, The China Journal, no. 43, pp. 101-10.

Zhao, Yaohui 2000, 'Rural-to-Urban Labor Migration in China: The Past and the Present' in West, Loraine A. \& Yaohui Zhao (eds.), Rural Labor Flows in China, Institute of East Asian Studies, University of California, Berkeley, pp. 15-33.

Zhao, Yaohui 1999, 'Labor Migration and Earnings Differences: The Case of Rural China’, Economic Development \& Cultural Change, vol. 47, no. 4, pp. 767-82. 